\title{
Education as Unfolding, Preparation and Growth: A Reflection from John Dewey's Perspectives and Its Implications to African Context
}

\author{
Mleke Bertha Richard Erick Elias Sele Antony Zakaria Fute Beatrice Fidelis Massawe \\ College of Teacher Education, Zhejiang Normal University (ZJNU) \\ 688, Yinbing Avenue, Jinhua City, Zhejiang Province, P.R. China, 321004
}

\begin{abstract}
Perhaps one of the concepts that have no single definition is 'education'. Over multiple of definitions of the term, at least we can say education can categorically be defined either as a process or as an outcome. This papers aims to describe John Dewey's perspectives on education, from the book of "Democracy and Education: An introduction to the Philosophy of Education" as he tries to describe the ongoing debate on whether education should be defined as a growth, as a preparation or as unfolding. The paper also raises some critiques on the conceptualization of education and it largely shows its implications to families, teachers or school managements as well as policy makers toward connecting the concepts of education with pedagogies as well as having the clear objectives on the education process. African countries need to consider that the process of education is designed differently from one country to another basing on the way education is conceptualized. If education is taken as unfolding or preparation, it is better for the curriculums, education policies, syllabuses as well as pedagogy to reflect the particular concept of education in articulated in such particular country.
\end{abstract}

Keywords: Education, Perspectives, Unfolding, Growth, Reflection

DOI: $10.7176 / \mathrm{JEP} / 10-9-14$

Publication date:March $31^{\text {st }} 2019$

\section{Introduction}

We can introduce this paper by reminding ourselves about the quotation from the then British Prime minister, Tony Blair who said "Ask me my three main priorities for government, and I tell you: education, education, education" (Tony Blair 1996). Education is something which is being prioritized by most of the countries' government in the word. This is because education is able to transform however human being wants to be transformed in his life, though the concept of education is not very much clear among the stakeholders and sometimes confused with schooling. Perhaps each African country individually needs to conceptualize its own definition of education. Such concept of education should firstly be defined by national goals as well as the same concepts should then define the process of education. The concept of education should explicitly define what $i s$ teaching? What is to be taught? And what is the role of student, school, parent and government in the education process?

Education can be defined as a development in the sense that children have got individual differences in terms of intellectual capabilities. In case where there are different students with different intellectual capabilities in the class, the role of the teacher should first be to identify those differences effectively and second to develop them accordingly. Teachers need to develop these intellects by designing teaching techniques which will treat every student respectively and not just equally (Equality vs. Equity). Example, slow learners must be considered during teaching, by developing strategies of keeping their paces resemble with other students who are either normal of fast learners. Schools should prepare environment where every student's potentials such as drawing, sports, designing and other potentials are fully developed. This is the time when the conception of education as a development will get to be realized and produce desired outcomes.

In African context, education, especially informal education is considered to be growth. From his birth, a child is under the guidance of adults trying to make him grow like adults and other members of the society. Societies are considered to be the standard of a child's good behavior measurement. This is why parents will struggle to make sure that during his physical growth, a particular child is surrounded by morally good people so that he can imitate slowly and become like them (adults). After adolescence, initiation ceremonies are held for African youths to be taught what they are expected to act in accordance to the society's norms. With this African context, a child is in the process of growing and any youth, who is able to behave or act in the way community members behave, he/she is considered to be grown up. With this conceptualization of informal education, all adults are expected and responsible to behave well for children to behave well too.

\section{The Concept of Education as Conceptualized by different Scholars}

The concept of education is never ceased to be debated among different scholars. This is because the concept itself is very important for defining the actual process of both formal and informal (non-formal) education. From 
etymological point, the word education is derived from the Latin word 'educare' which means 'to raise' and 'to bring up'. Basing on other few scholars too, the word 'education' has originated from another Latin term 'Educere' which means 'to lead forth' or 'to come out'. The meaning indicates that education aims to flourish the good qualities and draw out the best in every individual involved in it. Some other educationists also believe that the word 'education' has been derived from the Latin term 'Educatum', which means the act of teaching or training (NCERT, 2014)

Peters (1966), describes education as being something that we (society, community of formal schools) intend to transmit, and that what is transmitted is in a morally acceptable way and worthwhile. Asserting that the word education has normative implication, Elechi (2014) also quotes Peter, who proposed three criteria to the process, namely implying the transmission of what is worthwhile to those committed to it, involvement of knowledge, understanding and some kind of positive cognitive perspectives which are not inert and willingness or voluntariness of the learner. These are criteria against which to match the processes of education itself for fitness and he emphasizes that any process that does not satisfy these criteria, will not be called education and cannot result in the production of an educated man or any being.

Johan (2014) considers education as the only bridge that can take people to the better future. According to him, education is for future which is imagined by a person and for this person to reach that imagined future; he/she must cross over the bridge, the bridge which is education. The concept is significantly different from the conceptualization made by Holt (1964) who believes that a person can be considered educated, if he qualifies to live intelligently in today's world and be a useful member of a society. Holt continues to say that this will only depends on the amount of this essential knowledge that the so called educated carries about with him. So education is not about future but the present life and the way educated person is expected to face today's challenges. Education is an enterprise which aims at producing a certain type of people and the process is accomplished by the transmission of knowledge, skills, attitudes, values and understanding from one person to another (Moore, 2010). This implies that if education is transmitted from one to another, the receiver's head had nothing before the process. The receiver's head was like an empty tin or white paper, waiting the process to fill the knowledge in.

Education is a process which not only enables people to possess a mere know-how or knack, but also it enables the educated to have a body of knowledge and some kinds of conceptual scheme to raise and be in the level of collecting the disjointed facts and information as well as make them worthwhile to life. This also implies some understanding of principles for the organization of those facts (the body of knowledge and understanding of associated principles requirement) (Woods \& Barrow, 2006).

Bruner (1940) argues that the object of any learning, apart from pleasure it may give to the learner at a current time, it should also serve us in the future. Education should not only take us to somewhere, but it should allow us simply go further than where it places us, and this means education should take us to the more improved place compared to where we were before. Education serves us with our future in two ways. Firstly through the specific application of the knowledge to the tasks which are very similar to those we originally learned to perform (psychologically called transfer of knowledge) and secondly it helps in the way that the earlier learning renders later performances of tasks more efficiently (non-specific transfer of knowledge of principles)

To some extent, indeed, the postwar disputes which emerged between the modern analytical liberal educationalists of the intrinsic value and new educational utilitarian (Barrow, 1975) may be regarded re-runs of conflict about the purposes of education between utilitarian and such proponents of liberal education such as Matthew Arnold and John Henry Newman of $19^{\text {th }}$ century. According to Carr (2003), perhaps the key and important difference between older and the newer utilitarian accounts is that in the recent advocates of education as a means to human happiness and satisfaction seem to conceive more the external goods of education in wider cultural and civic, rather than the narrower cash benefit. All the same, it is likely that a broader utilitarian instrumental interpretation of education, motivated by a related Deweyan antipathy to the distinctions between theory and practice in education, has greatly influenced the criticisms of Peters' distinction between education and training, advanced by what might be called new vocationalists (Pring, 1994, 1995; Winch,2000, 2002).

Some other scholars define the concept of education referring to the human activity of preparing for life. It is concerned with not only children and young people, because one can be preparing himself or herself for different phases of life, it is better to say education is also concerned with adults who wish to re-establish or modernize the direction of their lives. However, to associate education with preparation for life is to reduce its content. There are different aspects of life such work, leisure and family and so it will depend on the view or perspective of future life someone has. Also different people and groups of people have different views about what are the most important and valued aspects of life. What is thought to be valuable on an aspect of life is closely connected with the values that people will hold (Winch \& Gingell, 2004).

\section{John Dewey's Perspectives on Education as Growth, Unfolding and Development Education as Growth}

From Dewey's perspectives, the native mechanism of the child and his impulses all tend to facile social 
responsiveness. Dewey does not fully concur with the statement that children, before their adolescence age, are egoistically self-centered; rather, it is the fact that their social responsiveness is employed on their own behalf. However, even when it exists, it is only because adults have shown these characters and have consequently interested them. According to Dewey, children seem to take behavior such as egocentrism or any other kind of behavior from adults surrounds them especially when such behaviors interest them. When a grown-up person (adult) is too busy in his or her own affairs in such a way that he/she fails to show an interest in children's affairs, children will undoubtedly focus only on their own affairs too, and so be considered as egocentric

As an adult develops objectives in his or her life, strategies to reach such objectives and be able to determine/predict the time to reach that goals, this ability is believed to get developed from early infancy age, as an infant requires about only six months to be able to gauge the action in reaching which will then be able to coordinate with his visual activities. In this time, the child will be able to tell whether he can reach a seen object and so he will be able to strategize the reaching. In learning one act and strategizing to reach a certain seen object, the methods are developed well so that they can be used in other context too. With this situation, John Dewey believes that human being acquires a habit of learning from the very early age. He learns to learn, however, the fact that the presence of dependence and learning is a stimulus to nurture and affection cannot be ignored at all.

\section{Habits as Expressions of Growth}

Dewey defines a habit as an ability to use natural conditions as means to ends. It is an active control of the environment by controlling the organs of action. He believes that human needs to control the environment more than being controlled by environment. The environment is sometimes thought of as something fixed, providing in its fixity the standard of changes taking place in the organism himself. In this situation, adjustment is needed for just fitting ourselves to this fixity of external conditions. Habit as habituation is defined as something relatively passive to conform to the environment and a change is to be done in the organism himself to cope with this external environment without reference to ability to modify surroundings.

Dewey is using an example of a savage tribe which managed to live on a desert plain by adapting itself, and its adaptation involved a maximum of accepting, tolerating, a maximum of passive acceptance or concurrence, and a minimum of active control of subjection to use as also adapts itself. But when civilized tribe lived in the same desert, it introduced irrigation as it was searching the world for plants and animals that would flourish under such conditions. It also improved by carefully selecting those which are growing there, as a result, the wilderness boomed as a rose. Dewey concludes the example by being very specific that the savage was merely habituated, while the civilized one was active and such activeness transformed the environment.

Habit is something which must be looked into its deeper conception so as to be able to develop it. Many people would naturally think of their use of tobacco, coffee, or disrespectful language as typical of the meaning of habit. To them, a habit is something which has a hold on them and not easily thrown away even when it is condemned to be bad. Habits reduce these people into a routine ways of doing to which we are enslaved just in the degree that our intelligence get disconnected from these behaviors (Un-thinking habits). Bad habits are habits so severed from reason that they are opposed to the conclusions of conscious decisions. The acquiring of these habits, especially bad ones is due to an original plasticity of our natures, the ability to differentiate responses until we find an appropriate way of acting. These routine habits possess us instead of them being possessed by us and so put an end to our plasticity.

\section{The Educational Bearings of the Conception of Development}

When it is said that education is development, everything depends upon how development is defined or conceptualized. In Dewey's view, life is development, and that developing and growing is life itself. When the concept is taken into educational value, that means that the educational process has no end beyond itself but it is its own end and that the educational process is one of continual reorganizing, reconstructing and transforming. When development is interpreted in comparative way, that is in regards to the special traits that are found in a child and adult life, it will means the direction of power into special channels, despite the fact that the normal child and normal adult alike are both engaged in growing. With regard to the development of powers devoted to coping with social, specific scientific and economic problems, we may say the child should be growing in manhood, but in regard to sympathetic curiosity, unbiased responsiveness, and openness of mind, we can as well say that the adult should be growing in childlikeness. There are three ideas which have been criticized by Dewey regarding this concepts and such ideas are namely the privative nature of immaturity, static adjustment to a fixed environment, and rigidity of habit. Growth is regarded as having an end instead of being an end. The educational counterparts of the three fallacious ideas have been failing to take into account the instinctive or native powers of the young, failure to develop initiatives in coping with novel situations as well as an undue emphasis upon drill and other devices which secure automatic skill at the expense of personal perception. In all cases, the adult environment is accepted as a standard for the child. 


\section{Education as Preparation}

As it has been laid down that the education process is a continuous process of growth and having its aim at every stage and an added capacity of growth. The first contrast is with the idea that education is a process of preparation or getting ready. What are to be prepared for are of course, the responsibilities and privileges of adult life. With this conception then, children are not regarded as social members in full consideration. They are looked upon as social members to be, members who are in the waiting list. The concept divides society into two groups of people, firstly the fully developed or prepared group and second, those who are preparing to become the members of the society.

John Dewey believes that children live in the present and the future life is just as future which lacks urgency and body. The future prepared for is as long as there will be time in between which will intervene before it will become a present. With the fact that future has no stimulating and directing power when severed from the possibilities of the present, something must be placed on to it so as to make it work. Promises of reward and threats of pain are employed in this kind of situation where what is prepared for is uncertain and of very long time to come. When this situation is happening, especially in education context, pupils have to be told that if they do not follow the prescribed course penalties will be upon them, and when they do, they may expect (sometime in the future) rewards for their present sacrifices

If education is growth indeed, it must not ignore the present situations, but progressively realize present possibilities, and so equip individuals better to cope with present first and then the later requirements. If the environment in school and outside the school supplies conditions which utilize adequately the present capacities of the immature, the future will grow itself from the present which is taken care of. Education should not be the preparation for future's need only, but making it useful to the current situation too

\section{Education as Unfolding}

Dewey tries to discuss the conception of education which professes to be based upon the idea of development (human development). According to this conception, development is conceived as the unfolding of human latent powers toward a certain definite goal, not as continuous growing. The two concepts differ in the sense that the development concept discusses the idea and the other makes much of the practical and professional duties for which one is preparing, but both are conceived to be transitional as they don't have meaning on their own account (they are just considered as movements toward something away from what is now going on). Since growth is just a movement toward a completed being, the final ideal is immobile. From the concept of unfolding, the teacher is expected to draw out from the pupil what is desired to be drawn out and when what is wanted is obtained, that will be the evidence that the child is unfolding well. The challenge is that the child does not have his own initiatives regarding to his potentialities and as a result, other people (adults) always furnish the formation of habit to these children.

Froebel and Hegel are the supporters of the idea that education is a process of unfolding. According to Hegel, unfolding is worked out through actuating force in which there is presentation of symbols, largely being mathematical which corresponds to the essential traits of the child. When these symbols are presented to the child, the whole perfection sleeping within him is just awakened to the absolute. Froebel recognizes the significances of the native capacities in a child, and his attention to children has influenced others to study the matter more although his formulation of the notion of development was badly challenged by the fact that he conceived development to be the unfolding of a ready-made latent principle. According to John Dewey, Froebel failed to understand that growing is growth and developing is development as he placed the emphasis to the completed product.

\section{Education as Training of Faculties}

The concept has a correct ideal that one outcomes of education to the learner should be the creation or formulation of specific power toward accomplishment and perfection. A trained person should be the one who can do things which are very important for him and in a better way than he could do without such training (doing the same thing, better that a person who did not receive such training could do). But this theory takes regards to some powers as the direct and conscious aims of teaching and learning, and not simply the as results of growth. There is definite number of faculties (power) to be trained because they are already there in some untrained form (crude form). Education is there to exercise these faculties in constant and graded repetitions so that at the end they become refined and perfected. The forms of powers of faculties that are mentioned to be focused in training includes perceiving, retaining, recalling, associating, attending, willing, feeling, imagining, thinking. In its classic form, this theory which focuses on training untrained faculties was expressed by John Locke.

Knowledge is taken to be produced when the mind is able to discriminate and combine things as they are united and divided in their natural form. But the very important thing for education, regarding this theory is the exercising of the faculties of the mind till they become well established habitudes to a human being. The conception has received critiques in its foundation as well as its application in education. Firstly, there are no such readymade powers (observation, recollection, willing, thinking) waiting to be exercised or trained as there is a great 
number of original native tendencies which are based on the original connections of neurons in the central nervous system, example the impulsive tendency of eyes to follow and fixate light, the neck muscles to turn toward light and sound, as well as the hands to reach and grasp. Secondly, the example of throat, un-intellectually making cough to eject the obnoxious particle and when the hand touches the hot thing, it is impulsively and un-intellectually snatched away. It is by these specific changes of organic activities in response to specific changes in the medium that is controlling the environment of which we have spoken is affected.

\section{Education process in Africa and reflections from John Dewey's conception of Education Formal Education and its Curriculum in Africa}

Curriculum in education is defined as the pre described content which is to be learnt by student in a particular level of education. Alexander (2009) conceptualizes curriculum in education as a key reference guide for teachers where it is encoded in a teacher's guide and official textbooks, so teachers' pedagogical approaches, strategies and practices in and outside the class should serve to enact the curriculum. Winch \&Gingell (2004) defines curriculum as all the activities which should go on in schools. All societies would like to pass on all cultural values from one generation to the next. In a complex society like what we are living in, it is better we associate the process with schooling and within our schools the main engine for delivering such cultural values is curriculum. Westbrook et al (2013) describes four models of curriculum that are found globally, especially in the developing countries namely Content-driven curricula, Process-driven curricula, Objective-driven curricula and Competency or outcome-based curricula

-Content-driven curricula. Subjects such as mathematics or science are used to describe the curriculum. This will lead students into accepting a given selection of content, organization and the pace of the knowledge in the relationship between the taught content and teachers so as to make sure that everything is covered from the curriculum. Knowledge is transmitted to a student in a situation where a teacher has a maximal control

-Process-driven curricula. In this type of curriculum, the content area stand in an open relation to each other and students will have more discretion over what is learnt compared to individual teacher who can also collaborate with other teachers from other discipline. In the process, there are various forms of assessment such as open ended assessment, course-work-based, formative or personal

-Objective-driven curricula. This is a type off curriculum which is structured basing on the learning outcomes described. The curriculum is designed in regard to the behavioral change and the specific context in which such behavior is expected to operate such as comprehending, applying, analyzing etc, starting with the lower level moving to the complexity. In this context, objectives or expected outcomes are given to the curriculum formulator and thus the curriculum will be formed basing on the prescribed objectives.

-Competence or outcome-based curricula. This is structured around sets of learning outcomes that learners are expected to achieve successfully at the end of learning process. Its assessment is organized in a way that it measures the learning than has happened. The curriculum is considered to train the learners become the life-long learners who can adopt better to the working world and it is considered to be more democratic.

Some of the African countries have a written curriculum while others do not have. With the countries which have curriculum, teachers and students need to comply with the content which is described in the curriculum document. In other way, to measure the level of understanding and learning outcomes, all students need to do one national examination which is prepared by the central government under the Ministry of Education through the departments which are responsible for examination formulation such as National Examination Council of Tanzania (NECTA). One of the assumptions held in this system is that the ability to pass examination is the best criterion for student selection and judging professional promise (Hall, 1986). Teachers also will need to make sure that at the end of the year, the content of a particular class is covered and students are selected to the next level of education or chosen to join various professions successfully. One who fails this exam is believed to be not educated well.

In this was way, we can consider this kind of education as un democratic for it does not give freedom for the particular society to choose what values are to be included in the curriculum and get transmitted to the next generation and which ones should not. It is true that if the curriculum is formulated by the central government, it will be very difficult to include cultural elements from every society, rather, the government will include only the most common values for the country that are thought to be very important. It is not democratic with another reason that students' individual differences in terms of talent are not considered. Students who are talented in sports, in tailoring design and other professionals which are not included in the curriculum, are displaced automatically from the system by s single unit of measurement called National examination. With this measurement Unit, those students who were good in sports but not very good in classroom subjects will be considered failures. In fact, schooling is the process which might be wasting time for not identifying some of the students' potentials.

According to John Dewey, schools should compliment to what the society has failed to teach their young generation because of the complexity of the society in which they live. Before formal education, one of the roles of the society was to make sure that young people become acceptable members in their particular societies. 
Introduction of formal education has brought about decay of native morals and the societies has left no right to decide what should and what should not be included in the curriculum. They send children to schools but they have no opportunity to decide what should be taught and what should not. According to John Dewey, schools should just complement what the society wish to transmit but it couldn't because of the growing complexity of the society

\section{Pedagogy in African schools}

In a very short description of pedagogy, Dewey defined it is teaching students how to learn and with this concepts, students need to learn how to learn. Pedagogy is the art and science of educating children, focusing on the relationship between learning and teaching such that one cannot exist as separate and distinct from the other. It includes terms like teaching design, teaching techniques, teaching methodologies, teaching procedures, teaching practices and instructions (Loughran, 2006). Pedagogy involves arranging content in a sequence in such a way that there will be continuity of knowledge during learning. It also involve designing what content needs more time than the other and techniques which will enable him/her to make all students understand the content

In the concept of education as unfolding, students are believed to have different potentials which are to be identified by their teachers and develop them. Teachers are expected to identify different learning styles from every student and comply with them without leaving any students behind. In a book written by Michael Gurian and Cathy Stevens (2011), titled "Boys and Girls learn differently", various biological (brain lateralization) and psychological (superiority and inferiority) factors are explained to show that in a class of boys and girls, a teacher needs to pay attention on the gender differences as it determine learning process. Without such idea in the teachers' mind, boys and girls are going to get left uneducated at different points of learning. Teachers for most of the time do not consider that gender difference means difference in learning style and so they teach by using a uniform pedagogy (strategy) throughout the teaching process and as the result, learning outcomes do differ from boys and girls in different discipline and topics. It is always concluded that girl students are good at writing compared to men, and men are good in spatial calculation compared to girls, without realizing that the teaching methodology in spatial calculation favored only boys and the teaching methodologies in writing skills favored only girls in a class. It was a responsibility of the teachers to make sure that he/she goes with both of them strategically

If we want to take our adults as standard of measurement for the grown up youths, we have to keep in mind that these adults including teachers are role models for their students and young people in the community. Students learn more from what is unconsciously taught by their teachers and so teachers should make sure they behave well in terms of wearing style, speaking style, time management and abiding to the rules. How can we use these adults as standard of measurement if they themselves don't comply with the cultural values and national rules as well as regulation? Many cases have been reported regarding teachers to have sexual affairs with their students in Africa and other continents as well. How can we say adults are standard of what children must become? In November $28^{\text {th }}$ 2018Mwananchi Newspaper from Tanzania reported about a teacher (Michael Ikila) who teaches at Nyakasongwa Secondary school in Sengerema District to get married to a student who passed form four exams and selected to join Mkinga Secondary in Tanga region, but the student could not join the school because that teacher had already made her a house wife. However the problem of misconducts to teachers is not for Africa only. In $10^{\text {th }}$ May 2015, an online magazine in UK called Mail Online (dailmail.co.uk) reported about a female teacher (Jenna Tarabelsi) in Massachusetts to have sex affairs with her students in the classrooms, at home and in school parking lot at different times. Jessica Fuchs (teachers) was also reported to get caught by her husband in her home, having sex with a 16 years boy in United States.

Although the problem is not only in Africa as explained in the example of the above cases, but if Africa particularly wants to make the continent more civilized, conserve the native African values and respect children' right more and even more compared to Europe and America, it should invest in moral education to its kids, Moral education which will infuse moral values in the school curriculum for teachers to impart to their students. Teachers should also be trained to behave according to the African social values because they are role models for African children. Do we want our children to become rappers? If not, then African countries need to consider cultural values in their curriculum, be transmitted and let them get documented instead of assuming our elders are always right and measurements of moral education success.

\section{Communities versus schools in Africa}

To emphasize on the point which is stated by John Dewey in his book "Education and democracy" that formal schools have to compliment where the society fails to do because of the growing complexity of our communities, conflict between what is going on in schools and what is expected by our communities should be resolved first. Actually most of the African societies are complaining for most of the graduates from formal schooling do forget or consciously deny their cultural values and instead, they tend to get affiliated more with western culture which is sometimes against the local culture in some of its elements. As a result most of the students do not traditionally fit to their societies and in the society two groups are created not only basing on formal education attainment, but 
also basing on the abiding to the traditional values. Those who comply with the traditional values are called conservatives in a negative way that they don't want positive change, and those who do not comply with the traditional values are called people with immoralities. Now the winner will be determined by the number of people in a particular group. If the group of formally educated people outnumbers the group of formally uneducated, there is a danger of losing the traditional values and identities as well

Here John Dewey was very true to say the role of communities should now be taken by formal schools in a sense that these schools should include in the curriculum what is perceived as good and important by the society. Curriculum in Africa needs to be formulated by Africans themselves basing on the local context. Winch \& Gingell (2004) are very right to define curriculum as all the activities the societies would like to pass on, including cultural values from one generation to the other. Winch says we associate the process with schooling and within our schools the main engine for delivering such cultural values is curriculum. Now what should be done when the curriculum turns our cultural values back? Reform is needed in curriculum to make sure these schools and communities share their objectives in the education process.

\section{Hunger and other calamities in the land of formally educated people}

Hunger is one of the challenges to most of the African countries despite having many university agricultural science graduates all over the continent. In $12^{\text {th }}$ October 2018, the website of Concern Worldwide US published a report with top ten countries with high hunger index in the world and among them, 6 were African countries namely Sudan, Madagascar, Sierra Leone, Zambia, Chad and Central African Republic. Many of these countries such as Sudan have shortage of rainfall as one of the reasons for hunger. Dewey emphasizes modern societies to change the environment instead of changing themselves to cope with the environment, he calls it habituation. Education should teach people how to learn and adjust the environment according to their needs. Education in Africa has got benefits if Africans decide to live a learning life continuously, which is different from what Dewey calls savage communities which lived in the desert and coped themselves to adjust with the environment. African education needs to prepare young people to solve the current challenges such as insecurities and hunger as well as teach them to learn for the future life when they will need to solve problems

Natural calamities such as earthquake, Ebola and malaria are challenging the continent. It is the responsibility of the formal education to educate people so that they will be able to avoid the calamity itself or at least avoid the impacts of them such as earthquakes. Education should train African youths to deal with the current problems first instead of preparing them more for the future problem. Preparing African youth for future does not pause the current problems from negatively affecting the continent, in fact these current problems matter more than the future problem, for future is uncertain as Dewey suggest. But current situation also can determine the future so we better invest more on solving the current problems than preparing our children for future. If we would prepare our youth to deal with the current problems such as corruption and unemployment, we could not get youths with potentialities that join terrorist groups because of money or religious extremism. Actually if African education would teach young people how to learn, there would be certainty that future problems will automatically solved because youths will learn by themselves as education taught them to do, and then solve all the problems.

\section{Conclusion}

Education can be defines as preparation, but it should not ignore the current African problems. Africa should be investing more on how to solve the current problems before we can imagine how to solve the future problems. Education can be defined as growth and adults to be the standard of measurement only if adults themselves will evaluate if they all fit to be the role models to African children. Teachers need to know that students are learning more than what they consciously teach. They learn even from their normal life and would like to become copy of their teachers. We can agree with the point that some African are born with potentialities but our education system fails to identify them and they are kept folded throughout their entire life. Our education system should be able to identify individual differences in potentials and be able to develop that giftedness for development of the continent. With this strategy of identifying every potential from every child in schools and developing them accordingly, then education will be considered as unfolding and development.

In educating African children, it is aimed to expose them to the types of things, adults and the government think are valuable and also enable them to suit and shine within our society after finishing their education. The type of education designed for children in African should then suit to these objectives and projection; this is to say curriculum designing should be given more consideration in reflection to the social prescribed objectives. It must be relevant to those being educated and their society too. If such education is relevant it will also be relevant for someone and in relation to some purpose that person has or might have. For example, home economics is a relevant thing to teach girls because in being a girl, especially in the traditional societies, the home will be the focus of their future interests. But such assumptions both about girls' nature and their future interests must be accompanied with making them live and enjoy their current life as well as solve the problems that are patterned with such life. For education system in Africa as well as other parts of the world to offer chances, benefits and choices to those being 
educated both during and after school, we must avoid such assumptions of connecting education with only the future life.

\section{References}

1. Carr D (2003) "Philosophy and the meaning of education "SAGE Publications, Thousand Oaks and New Delhi, Vol 1 (2) 195-212 [1477-8785

2. Bruner J (1940) “The process of Education” Harvard University Press, Cambridge, Massachusetts, LondonEngland

3. Loughram J (2006) "Developing a Pedagogy of Teacher Education: Understanding teaching and learning about teaching” 2 Park Square, Milton Park, Abingdon, Oxon-USA

4. Ekwueme G (2014) "Richards S. Peters' Concept of Education and the Educated Man: Implications for Leadership Recruitment in Nigeria” Journal of education and Practice, Vol.4, No.23, 2014

5. Harlan J \& Johan R. (2014) "Education Nowadays" International Journal of Educational

Science and Research (IJESR) Vol. 4, Issue 5 pp 51-56

6. Boldacchino, J. (2008) “The praxis of art'sdeschooled practice, International Journal of Art

\& Design Education”, Vol. 27, No. 3, pp. 241-50

7. Downing, D. \& Watson, R. (2004) "School Art: What's in It?: Exploring Visual Arts in Secondary Schools" Slough: National Foundation for Educational Research

8. Adams J et al (2008) "Teaching Through Contemporary Art: A Report on Innovative Practices in the Classroom”. Blackwell Publishing Limited pp 1-66

9. Dewey J (1915) "democracy and education: An Introduction to the Philosophy of Education" AAKAR Books Publishers, Mayur Vihar Phase-I, Delhi

10. Woods R. \& Barrow R (2006) “An introduction to Philosophy of education (4 ${ }^{\text {th }}$ Ed)” Rutledge Publishers, New York, USA

11. Moore T (2010) "Philosophy of Education: An Introduction" Rutledge Publishers, New York, USA

12. Moon B (2012) "Art Therapy Teaching as Performance Art", Journal of the American Art Therapy Association, 29:4, 192-195,

13. Samuelsson P. et al (2014) "The art of teaching children the art: Music, dance and poetry with children aged 2-8 years old", International Journal of Early Years Education, Vol. 17, No. 2, pp 119-135

14. NCERT (2014) "Basics in Education: Textbook for B. Ed. Course" National Council of Educational Research and Training (NCERT), ISBN 978-93-5007-283-7 